\title{
Pollutants in Bottom Sediments in the Balaklava Bay (the Black Sea)
}

\author{
E. A. Kotelyanets ${ }^{1}$, , K. I. Gurov ${ }^{1}$, E. A. Tikhonova ${ }^{2}$, S. I. Kondratev ${ }^{1}$ \\ ${ }^{1}$ Marine Hydrophysical Institute of RAS, Sevastopol, Russian Federation \\ ${ }^{2}$ A.O. Kovalevsky Institute of Biology of the Southern Seas, Russian Academy of Sciences, \\ Sevastopol, Russian Federation \\ *plistus@mail.ru
}

Purpose. The purpose of the paper consists in studying the pollution level, and the character of spatial distribution of microelements and trace metals, the chlorophorm-extractable substances and petroleum hydrocarbons and in evaluating the features of their accumulation in the upper layer of bottom sediments in the Balaklava Bay depending on the natural and anthropogenic sources of pollutants.

Methods and Results. The samples were taken from the bottom sediments upper layer $(0-5 \mathrm{~cm})$ in the Balaklava Bay by the Peterson grabber in February, 2015. Location of the sampling stations was chosen proceeding from the features of the bay morphometry, hydrological and hydrochemical water structure, pollution sources and the character of the sedimentation processes. The samples were selected, preprocessed and analyzed by the standard methods according to the regulatory documents. Some changes in relation between the clay fractions and the gravel material composition were revealed. The correlation dependence between the contents of chlorophorm-extractable substances and petroleum hydrocarbons was calculated. The features of spatial distribution of the metals' content depending on the natural geochemical processes in the bottom sediments are revealed. The regions subjected to the most intensive anthropogenic load within the region under study are distinguished.

Conclusions. The content of clay material in all the samples taken in the Balaklava Bay on the average increased from 58.2 to $65.9 \%$ and its maximum values are still concentrated in the western and northwestern parts of the water area under study. During last ten years, growth of the portion of a fine-grained material in the bottom fractions has been noted; at that the places where it accumulats are located in the areas of intense anthropogenic activity. The chlorophorm-extractable substances concentration in the Balaklava Bay bottom sediments varied within a wide range. On the whole, in course of the investigated period their content decreased, whereas the petroleum hydrocarbons concentration remained unchanged. It is found that pollution of the bottom sediments by metals is of a polyelemental nature and is characterized primarily by such metals as $\mathrm{Pb}, \mathrm{Cr}, \mathrm{Zn}, \mathrm{Cu}$ and Sr. The increased microelements concentrations are observed in the northeastern and central parts of the water area, whereas the decreased metal concentrations - in its northwestern and eastern parts.

Keywords: Black Sea, Balaklava Bay, bottom sediments, granulometric composition, trace metals, chlorophorm-extractable substances, petroleum hydrocarbons.

Acknowledgements: the investigation was carried out within the framework of state task on the theme No. 0827-2019-0004 "Complex interdisciplinary investigations of the oceanologic processes conditioning functioning and evolution of the Black and Azov seas' ecosystems of the coastal zones" and State assignment of IBSS RAS on theme "Molismological and biogeochemical foundations of the marine ecosystems homeostasis" No. AAAA-A18-118020890090-2 with support of the RFBR project No. 18-45-920007 "Geochemistry of bottom sediments pollutants of the Balaklava Bay (the Black Sea)".

For citation: Kotelyanets, E.A., Gurov, K.I., Tikhonova, E.A. and Kondratev, S.I., 2019. Pollutants in Bottom Sediments in the Balaklava Bay (the Black Sea). Physical Oceanography, [e-journal] 26(5), pp. 414-424. doi:10.22449/1573-160X-2019-5-414-424

DOI: $10.22449 / 1573-160 \mathrm{X}-2019-5-414-424$

(C) 2019, E. A. Kotelyanets, K. I. Gurov, E. A. Tikhonova, S. I. Kondratev

(C) 2019, Physical Oceanography 


\section{Introduction}

Currently, more and more attention is paid to the problem of coastal water contamination by such pollutants as heavy metals, oil and oil products. Water areas of the coastal strip intensively used for ship berthing or as the places of industrial enterprises location, are most exposed to the pollution. An important source of water pollution is river and storm runoff. The pollutants enter the sea water, fall to the bottom and are deposited in the bottom sediments. Thus, bottom sediments are an important link in the ecological equilibrium chain and serve as indicators of the man-induced impact intensity.

Pollutants are distributed in water bodies unevenly, forming the areas of increased pollution in the euphotic layer, frontal zones and the surface layer of bottom sediments $[1,2]$. Sustainable pollution characterizes the water areas of bays and estuaries, in which dissimilar water masses converge [2, 3]. The content and distribution of pollutants in bottom sediments depend on the location of pollution sources, as well as on the oceanographic characteristics of the water area.

The Balaklava Bay is an area with limited water exchange, actively exploited by humans. Over a long period of intense man-induced load, a significant amount of pollutants has accumulated in its bottom sediments. Based on the bottom morphometry and coastal configuration, the Balaklava Bay is divided into a shallow part at the apex, central part, southern deep-water extension and kneeshaped narrowness connecting the last two parts [4].

During the studies carried out in 2005 [5], the level of bottom sediments contamination was estimated by some micro elements and petroleum hydrocarbons. It was revealed that bottom sediments at the bay apex and in its central part are typically man-made silts, which differ from natural sediments in geochemical and lithodynamic parameters. The maximum concentrations of heavy metals and xenobiotic organic substances exceeded the background content of metals on the shelf of the Crimean Peninsula [1,2]. In the Balaklava Bay the total content of heavy metals $(\mathrm{Cd}, \mathrm{Cu}, \mathrm{Ni}, \mathrm{Pb}, \mathrm{Ag}, \mathrm{Zn})$ in the bottom sediments $(521 \mathrm{mg} / \mathrm{kg})$ was higher than in the Sevastopol Bay $(371 \mathrm{mg} / \mathrm{kg})$ [6]. For comparison: in some areas of the adjacent coastal waters of the World Ocean, the total heavy metal pollution of bottom sediments is, for example, 52$16400 \mathrm{mg} / \mathrm{kg}$ in the harbors of the Mediterranean region [7], $2710 \mathrm{mg} / \mathrm{kg}$ in New Bedford Harbor, USA [8] and 51.5-400 mg/kg in the Turkish coast region [9].

In the works on the Black Sea and its northwestern shelf monitoring [10-12] the fact that the accumulation rate of micro elements and heavy metals in the bottom sediments depends on their granulometric distribution was shown.

The purpose of this work is to investigate the pollution level and the spatial distribution of trace elements and heavy metals, chloroform-extractable substances (CES) and petroleum hydrocarbons (PH), to evaluate the features of their accumulation in the surface layer of the Balaklava Bay bottom sediments depending on the natural ( particle size distribution) and man-made input sources.

The obtained data were compared with the results of observations in 2005 [5]. The correlation coefficients between the content of trace elements, heavy metals and granulometric distribution were calculated. 


\section{Areas of work, materials and research methods}

Samples of bottom sediments were taken in the Balaklava Bay from the upper sediment layer $(0-5 \mathrm{~cm})$ by Peterson grab in February 2015. The location of the stations at which the samples were taken was selected based on the features of the bay morphometry, hydrologic-hydrochemical structure of waters, potential sources of pollution and nature of sedimentation processes (Fig. 1).

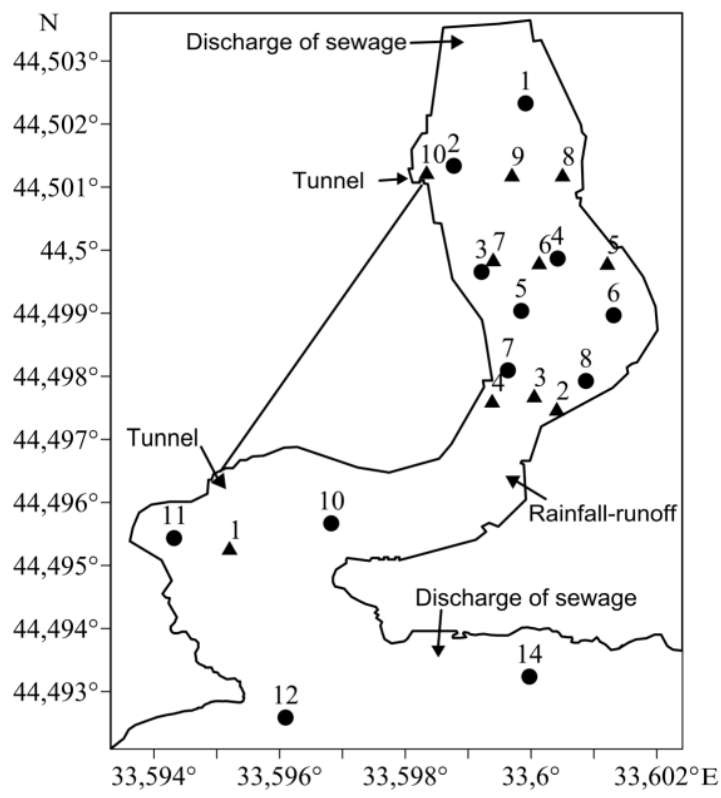

F i g. 1. Scheme of the stations of bottom sediments sampling for analyzing the metals bulk content and the features of the sediment fractions spatial distribution $(\bullet)$; for determining chlorophormextractable substances (CES) and petroleum hydrocarbons $(\mathrm{PH})(\mathbf{\Delta})$

Total content of $\mathrm{Cr}, \mathrm{Co}, \mathrm{Cu}, \mathrm{Ni}, \mathrm{Pb}, \mathrm{Zn}, \mathrm{V}, \mathrm{Sr}$ metals and $\mathrm{TiO}_{2}, \mathrm{MnO}, \mathrm{Fe}_{2} \mathrm{O}_{3}$ metal oxides in the bottom sediments was determined by $\mathrm{X}$-ray fluorescence analysis (XRF) using SPECT-ROSKAN MAX-G spectrometer by NPO "SPECTRON" (Russia) 1 .

The separation of aleurite-pelitic fraction $(\leq 0.05 \mathrm{~mm})$ was performed by wet sieving with the subsequent gravimetrical determination of the dry mass. Coarse fractions $\left(>0.05 \mathrm{~mm}\right.$ ) were separated by a sieve method of dry sieving ${ }^{2}$ using standard sieves (GOST 12536-2014).

In order to determine the chloroform-extractable substances (CES) and petroleum hydrocarbons $(\mathrm{PH})$, bottom sediment sampling was carried out in the summer of 2005 (Fig. 1) by the staff of the Department of Marine Sanitary Hydrobiology of Federal State Budgetary Institution A.O. Kovalevsky Institute

${ }^{1}$ Gosstandart, 2002. [Technique for Measuring the Mass Fraction of Metals and Metal Oxides in Powder Samples of Soils by X-ray Fluorescence Analysis. M049-P/02. Certificate of Gosstandart of the Russian Federation No. 2420/53-2002]. Saint Petersburg: Spectron, 16 p. (in Russian).

${ }^{2}$ Petelin, V.P., 1967. [Granulometric Analysis of Marine Bottom Sediments]. Moscow: Nauka, 128 p. (in Russian). 
of Biology of the Southern Seas of RAS. In appropriately prepared air-dry samples the amount of CES was determined by the gravimetric method and the one of PH by IR spectrometry ${ }^{3}$.

\section{Research results and their discussion}

According to $[1,5,13,14]$, the bottom sediments of the bay are predominantly represented by fine silts and silty sands with inclusions of separated shells and shell detritus; an increase in the proportion of coarse-grained stone gravel is noted near the coast.

Studies of granulometric composition of bottom sediments taken in 2015 showed that the material composition and spatial distribution of individual fractions underwent some changes compared to 2005 data (Fig. 2, b).
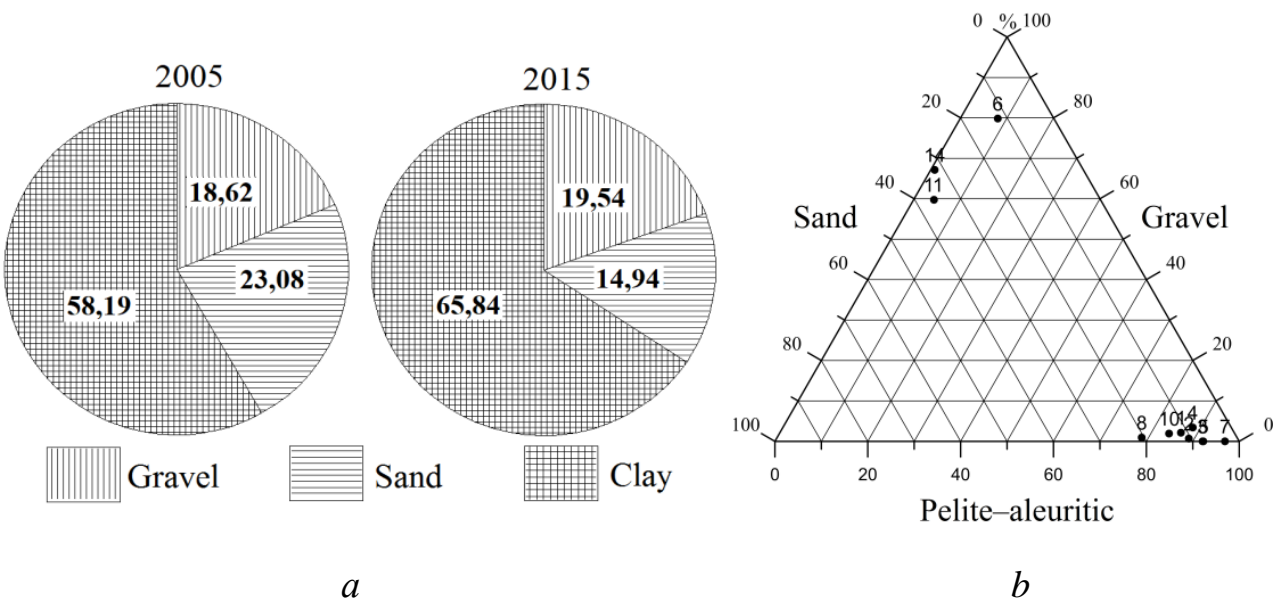

F i g. 2. Features of granulometric composition of the Balaklava Bay bottom sediments: circular graphs - for 2005 and 2015 (a); three-component graph - for 2015 (b)

In the samples taken in 2005 the content of the aleurite-pelitic fraction $(<0.05 \mathrm{~mm})$ was, on average, about $13 \%$, and in 2015 samples it reached $50 \%$. The change in the proportion of silt fractions was reflected in the median diameter value, which decreased to $0.06 \mathrm{~mm}$. In the north-eastern apex part the content of silt material increased from 55 to $86 \%$, in the north-western apex part - from 72 to $90 \%$. In the central part of the water area the proportion of aleurite-pelitic material increased by $15 \%$.

Changes in the material composition of gravel material were revealed. In the 2015 samples, coarse-grained and fine-grained shell material prevails, and the average value of the median diameter for the gravel fraction was 2.68. As for the spatial distribution, the proportion of coarse-grained material in the coastal eastern part of the water area decreased from 84 to $78 \%$, and the proportion of silt in the same part increased from 1.3 to $8 \%$. The fraction of silty sands in the surface layer of bottom sediments decreased from 23.08 to $14.9 \%$.

\footnotetext{
${ }^{3}$ Oradovsky, S.G. ed., 1977. [Guidance on Methods of Analysis of Sea Water]. Saint Petersburg: Gidrometeoizdat, pp. 118-131 (in Russian).
} 
It is noted that for increased concentrations of trace elements such as copper, nickel, chromium, vanadium, titanium, iron and manganese a high positive correlation with the silt fraction in the surface layer of the Balaklava Bay bottom sediments (Fig. 3) is observed.

An analysis of the obtained results showed (Fig. 4) that CES concentration in the bottom sediments of the Balaklava Bay in 2005 varied widely from 39 to $970 \mathrm{mg} / 100 \mathrm{~g}$ of air-dry matter. These values correspond to I-III levels of pollution of bottom sediments according to [1].

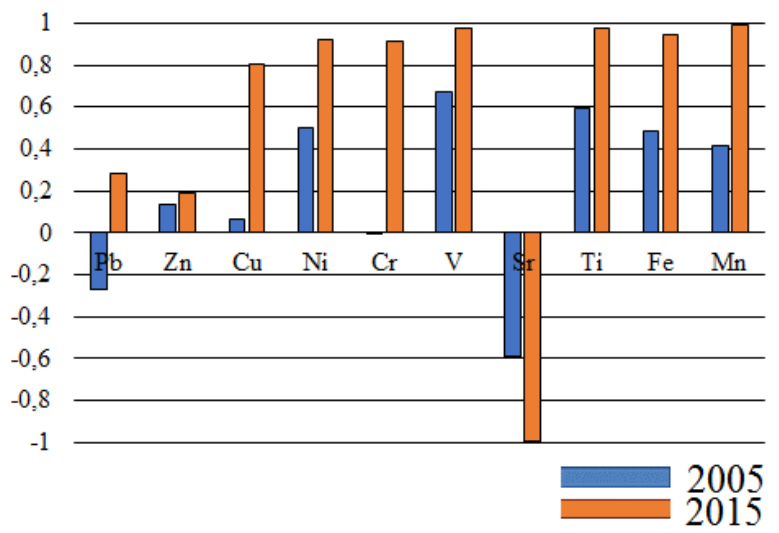

F i g. 3. Correlation coefficients between the contents of the clay fraction and the metals in the Balaklava Bay bottom sediments

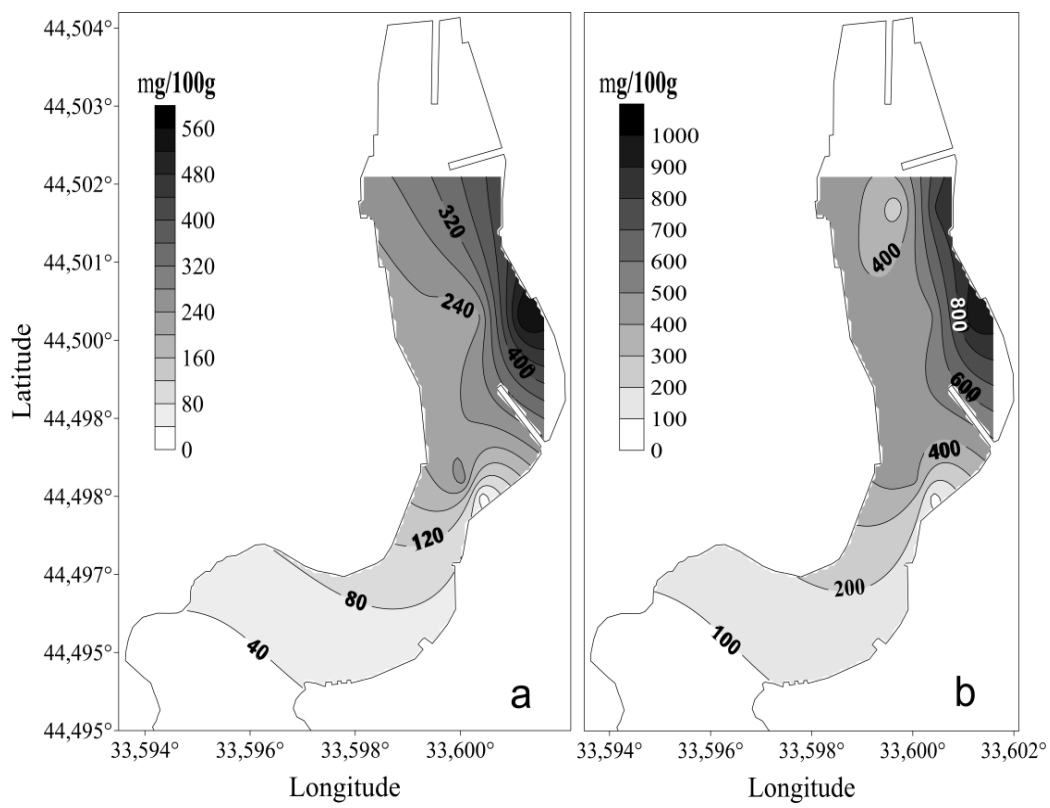

F i g. 4. Spatial distribution of petroleum hydrocarbons $(a)$ and chlorophorm-extractable substances (b) in the Balaklava Bay bottom sediments 
Previously (in [1]), levels III - IV were noted in the studied water area. This division into levels (from I to $\mathrm{V}$ ) was carried out in accordance with the CES content in bottom sediments and the reaction of the benthic community to it. The first level corresponds to naturally pure marine sediments with high biodiversity, and the fifth corresponds to almost lifeless bottom sediments [15].

CES content in 2005 decreased compared to 1992 (190-2690 mg/100 g), which is probably due to a decrease in the load on the bay in the $90 \mathrm{~s}$, whereas the $\mathrm{PH}$ content remained at the same previously fixed level (in 2005 - from 44 to $582 \mathrm{mg} / 100 \mathrm{~g}$ of air-dry matter, in 1992 - from 21 to $562 \mathrm{mg} / 100 \mathrm{~g}$ of air-dry matter). The percentage of PHs from CES in 2005 was $32-61 \%$ versus $17-28 \%$ in 1992. The obtained indices testify to the hydrocarbon nature of crude organic matter.

At the same time, a direct correlation between CES and PH content $(r=0.98)$ was observed and the distributions of chloroform-extractable substances and petroleum hydrocarbons were similar: the maximum concentration values were observed in the central part of the bay and the minimal ones - at its outlet. In 2005 , in the areas of increased $\mathrm{PH}$ content an increased content of metals (such as $\mathrm{Pb}, \mathrm{Zn}$, $\mathrm{Cr}$ ) was noted. The resulting distribution of pollutants can be due to several causes: the features of the bay hydrological regime (currents, water area closure, etc.), the granulometric composition of bottom sediments (in the silt fraction the concentration of pollutants is more intense) and their sources (increased concentrations of these elements are observed in the area of the storm runoff outlet of Balaklava) $[5,16,17]$.

From 1992 to 2005 a trend toward CES decrease in the bottom sediments of the Balaklava Bay is noted. It is also known that in the muddy marine sediments the accumulation of pollutants occurs more intensively. Due to the fact that, according to our data, the granulometric composition of bottom sediments over the past decade has changed in the direction of increasing silt fractions, we can assume a higher level of water pollution than previously noted one.

Groups of trace elements distinguished by the features of spatial distribution are selected. The first group includes $\mathrm{Zn}, \mathrm{Co}, \mathrm{Cr}$, Fe, Sr (Fig. 5, a), the distribution of these metals is characterized by maximum concentrations in the central part of the bay. Their localization on this site is observed near the eastern and western shores. Elevated concentrations of these elements are determined in the region of the studied water area where the storm runoff of Balaklava is located [4], while the concentration values in the water area centerline are significantly lower. Such a spatial distribution is typical for the water area in 2005. The second group of trace elements includes $\mathrm{V}$, Ti, Mn (Fig. 5, b). Their spatial distribution has an inverse relationship: maximum concentrations were observed closer to the coastline of the bay.

The third group of elements is represented by $\mathrm{Pb}, \mathrm{Ni}, \mathrm{Sr}$ (Fig. 5, c). Their distribution is characterized by local heterogeneity. Maximum concentrations were observed both in the coastal zone and in the central part of the Balaklava Bay.

The spatial distribution of $\mathrm{Cu}$ (Fig. 5, c) is characterized by maximum concentrations in the shallow part at the bay apex $(49 \mathrm{mg} / \mathrm{kg})$ and at the exit from the knee-like narrowness of the studied water area $(90.6 \mathrm{mg} / \mathrm{kg})$. 

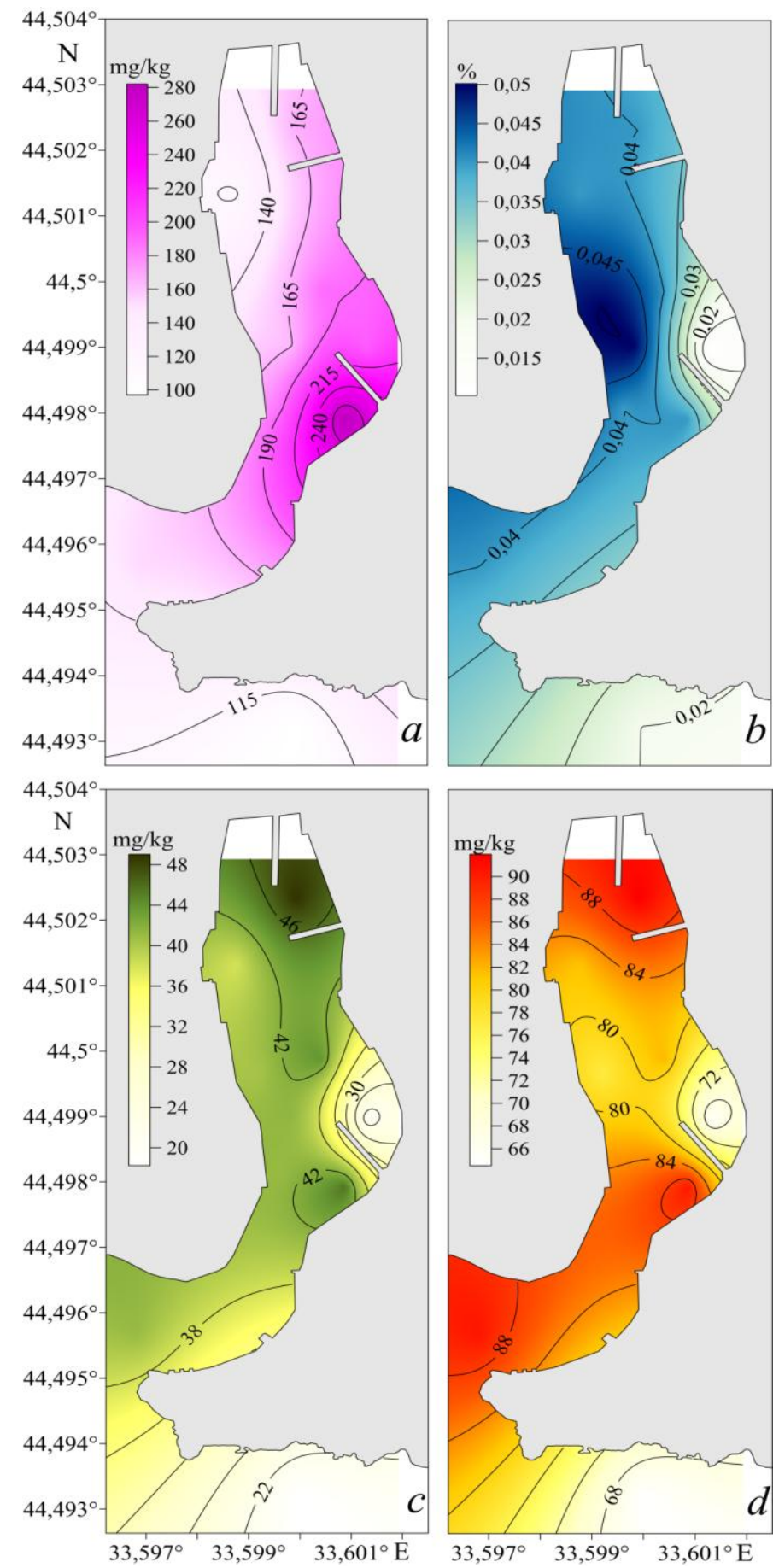

F i g. 5. Spatial distribution of contents of zink (a), manganous oxide $(b)$, nickel $(c)$ and black copper (d) in the Balaklava Bay bottom sediments (2015) 
The results of determining the total metal content in the surface layer of the bay bottom sediments are presented in the table.

Maximum $\left(\mathrm{C}_{\text {max }}\right)$ and minimum $\left(\mathrm{C}_{\text {min }}\right)$ values of the metals total content $(\mathrm{mg} / \mathrm{kg})$ in the Balaklava Bay bottom sediments

\begin{tabular}{c|ccc|c}
\hline \multirow{2}{*}{ Element } & \multicolumn{2}{|c|}{2015} & \multicolumn{2}{c}{2005} \\
\cline { 2 - 5 } & $\mathrm{C}_{\min }$ & $\mathrm{C}_{\max }$ & $\mathrm{C}_{\min }$ & $\mathrm{C}_{\max }$ \\
\hline $\mathrm{Pb}$ & 18.04 & 188.62 & 28.41 & 504 \\
$\mathrm{Zn}$ & 97.12 & 283.16 & 94.4 & 359.10 \\
$\mathrm{Cr}$ & 26.06 & 87.19 & 57.54 & 86.43 \\
\hline
\end{tabular}

The distribution of nickel, cobalt, vanadium, titanium, iron and manganese in the surface layer of bottom sediments is determined by the sorption properties of fine pelite-aleuritic silts, which confirms the previously obtained data for other water areas of the Sevastopol region [3].

A negative correlation between fine-grained sediments and such elements as $\mathrm{Pb}$ and $\mathrm{Sr}$ was noted, as well as a positive one between $\mathrm{Sr}$ and the content of gravel material.

An analysis of the results showed that the average content of cobalt, copper, and strontium slightly decreased compared to the content of these elements in 2005 [5].

The content of lead, which is an anthropogenic pollutant [18], in the Balaklava Bay bottom sediments is local and often depends on the input source. Significant concentration gradients of $\mathrm{Pb}(188.62 \mathrm{mg} / \mathrm{kg})$ were determined in the central part of the bay, which is typical for high-carbonate silts [2] and coarse pelite and aleurite fractions. The average concentration of $\mathrm{Pb}$ in the bay decreased compared with 2005 data and amounted to $73.14 \mathrm{mg} / \mathrm{kg}$.

The increased chromium content is observed in places of accumulation of vessels and in the water areas of ports [18]. Chromium enters the study area with river waters. It was noted that the average $\mathrm{Cr}$ content in the bottom sediments of the Balaklavka River, which flows into the Balaklava Bay, was $66.13 \mathrm{mg} / \mathrm{kg}$. Coming with river runoff, $\mathrm{Cr}$ accumulates in the upper part of the bay and in the central part of the water area; its maximum concentrations vary within 70.25 $87.19 \mathrm{mg} / \mathrm{kg}$ range. In general, the content of this element in the bay bottom sediments does not exceed the average values obtained for sediments of the Black Sea shelf [2].

The spatial distribution of $\mathrm{Zn}$ is similar to one of $\mathrm{Cr}$. It was noted that the maximum concentration of zinc is $283.15 \mathrm{mg} / \mathrm{kg}$, which is almost six times higher than its average content in the Black Sea shelf sediments [2].

\section{Conclusion}

The obtained results showed that over the past 10 years the correlation of fractions of granulometric distribution of bottom sediments has changed. This primarily relates to silty material, the content of which in the surface layer PHYSICAL OCEANOGRAPHY VOL. 26 ISS. 5 (2019) 
increased on average from 58 to $66 \%$, in particular due to an increase in the proportion of the pelite-aleuritic fraction from $13 \%$ in 2005 to $50 \%$ in 2015 . The content of coarse-grained material increased, but the average median particle diameter of the gravel fraction decreased. It is shown that the proportion of silty sand in the Balaklava Bay sediments decreased from 25.4 to $12.8 \%$.

A correlation analysis of the relationship between the content of trace elements and heavy metals with particle size distribution is performed. The metals (Ni, Cr, V, Ti, Fe, Mn) which in 2005 and 2015 showed a statistically significant correlation with the silt fraction of the studied bottom sediments were selected. This relationship was traced in the waters of both the Sevastopol Bay and the Kerch Strait [19, 20].

The concentration of CES in the bottom sediments of the Balaklava Bay varied widely. In 2005 their content decreased compared to 1992, which is probably due to a drop in the anthropogenic load on the bay in the 90s. PH content in 2005 (from 44 to $582 \mathrm{mg} / 100 \mathrm{~g}$ of air-dry matter) remained at the level recorded in 1992 (from 21 to $562 \mathrm{mg} / 100 \mathrm{~g}$ air-dry matter). A direct correlation between CES and PH content $(\mathrm{r}=0.98)$ was observed.

CES distribution in the bottom sediments of the studied water area corresponds to $\mathrm{PH}$ distribution: the maximum indicators are recorded in the central part of the bay, and the minimum ones - at the exit from it. In the areas of high $\mathrm{OH}$ content in 2005, an increased content of metals such as lead, zinc and chromium was noted.

The analysis of the obtained data shows that in the samples taken in 2015 and 2005 such metals as lead, chromium, zinc, copper, and strontium predominate. The average content of cobalt, copper, strontium slightly increased compared with the content of these elements in 2005. At the same time, the average lead content in the samples of $2015(73.14 \mathrm{mg} / \mathrm{kg})$ decreased by almost 1.5 times compared to $2005(125 \mathrm{mg} / \mathrm{kg})$. The maximum concentrations of metals $(\mathrm{Cr}, \mathrm{Cu}, \mathrm{Pb}, \mathrm{Zn})$ are observed in the central part of the Balaklava Bay. Their localization is observed off the eastern and western shores of the water area.

It has been shown that an increase in the concentration of trace elements is noted in the apex northeastern and western parts of the water area. In the apex northwestern and central parts a significant decrease in the concentrations of the studied metals is observed.

\section{REFERENCES}

1. Mironov, O.G., Kiryukhina, L.N. and Alyomov, S.V., 1999. Complex Ecological Survey of the Balaklava Bay (the Black Sea). Ecology of the Sea, (49), pp. 16-21 (in Russian).

2. Mitropolsky, A.Yu., Bezborodov, A.A. and Ovsjany, E.I., 1982. [Geochemistry of the Black Sea]. Kiev: Naukova dumka, 144 p. (in Russian).

3. Kadoshnikov, V.M., Shkapenko, V.V., Gorlitsky, B.O., Pisanskaja, I.R. and Smirnova, Yu.D., 2011. Heavy Metals in Bottom Sediments of Sevastopol Bay. Mineralogical Journal, 33(4), pp. 73-79 (in Russian).

4. Lomakin, P.D. and Popov, M.A., 2011. Oceanological Characteristic and Estimation of the Water Pollution in the Balaklava Bay. Sevastopol: EKOSI-Gidrofizika, 184 p. (in Russian).

5. Ovsyany, E.I., Kotelyanets, E.A. and Orekhova, N.A., 2009. Arsenic and Heavy Metals in the Bottom Sediments of the Balaklava Bay (Black Sea). Physical Oceanography, [e-journal] 19(4), pp. 254-266. https://doi.org/10.1007/s11110-009-9048-4 
6. Burgess, R.M, Terletskaya, A.V., Milyukin, M.V, Povolotskii, M., Demchenko, V.Y., Bogoslavskaya, T.A., Topkin, Yu.V., Vorobyova, T.V. and Petrov, A.N. [et al.], 2009. Concentration and Distribution of Hydrophobic Organic Contaminants and Metals in the Estuaries of Ukraine. Marine Pollution Bulletin, [e-journal] 58(8), pp. 1103-1115. https://doi.org/10.1016/j.marpolbul.2009.04.013

7. Sprovieri, M., Feo, M.L., Prevedello, L., Manta, D.S., Sammartino, S., Tamburrino, S. and Marsella, E., 2007. Heavy Metals, Polycyclic Aromatic Hydrocarbons and Polychlorinated Biphenyls in Surface Sediments of the Naples Harbour (Southern Italy). Chemosphere, [e-journal] 67(5), pp. 998-1009. https://doi.org/10.1016/j.chemosphere.2006.10.055

8. Ho, K.T., Burgess, R.M., Pelletier, M.C., Serbst, J.R., Ryba, S.A., Cantwell, M.G., Kuhn, A. and Raczelowski, P., 2002. An Overview of Toxicant Identification in Sediments and Dredged Materials. Marine Pollution Bulletin, [e-journal] 44(4), pp. 286-293. https://doi.org/10.1016/S0025-326X(01)00251-X

9. Topcuoğlu, S., Kırbaşoğlu, Ç. and Güngör, N., 2002. Heavy Metals in Organisms and Sediments from Turkish Coast of the Black Sea, 1997-1998. Environment International, [e-journal] 27(7), pp. 521-526. https://doi.org/10.1016/S0160-4120(01)00099-X

10. Bat, L., Yesim Özkan, E. and Can Öztekin, H., 2015. The Contamination Status of Trace Metals in Sinop Coast of the Black Sea, Turkey. Caspian Journal of Environmental Sciences, 13(1), pp. 1-10. Available at: https://cjes.guilan.ac.ir/article_112_4a666ae9d2870de30036717ef4f9a5d0.pdf [Accessed: 01 October 2019].

11. Eckert, S., Schnetger, B. and Brumsack, H.-J., 2009. Trace Metal Patterns in Black Sea Sapropels as a Chemostratigraphic Tool. Geophysical Research Abstracts, 11, EGU2009-9371. Available at: https://meetingorganizer.copernicus.org/EGU2009/EGU2009-9371.pdf [Accessed: 01 October 2019].

12. Tankéré, S.P.C., Muller, F.L.L., Burton, J.D., Statham, P.J., Guieu, C. and Martin, J.-M., 2001. Trace Metal Distributions in Shelf Waters of the Northwestern Black Sea. Continental Shelf Research, [e-journal] 21(13-14), pp. 1501-1532. https://doi.org/10.1016/S0278-4343(01)00013-9

13. Gurov, K.I., Ovsyany, E.I., Kotelyanets, E.A. and Konovalov, S.K., 2015. Factors of Formation and Features of Physical and Chemical Characteristics of the Bottom Sediments in the Balaklava Bay (the Black Sea). Physical Oceanography, [e-journal] (4), pp. 46-52. doi:10.22449/1573160X-2015-4-46-52

14. Orekhova, N.A., Ovsyany, E.I., Gurov, K.I. and Popov, M.A., 2018. Organic Matter and GrainSize Distribution of the Modern Bottom Sediments in the Balaklava Bay (the Black Sea). Physical Oceanography, [e-journal] 25(6), pp. 479-488. doi:10.22449/1573-160X-2018-6-479488

15. Mironov, O.G., Milovidova, N.Y. and Kirjukhina, L.N., 1986. [About the Maximum Permissible Concentrations of Oil Products in Bottom Sediments of the Coastal Zone of the Black Sea]. Hydrobiological Journal, 22(6), pp. 76-78 (in Russian).

16. Mezentceva, I.V., Chaikina, A.V. and Klimenko, N.P., 2003. Modern State of Pollution of the Balaklava Bay Waters. In: MHI, 2003. Ecological Safety of Coastal and Shelf Zones and Comprehensive Use of Shelf Resources. Sevastopol: MHI NANU. Iss. 8, pp. 115-118 (in Russian).

17. Kuftarkova, Ye.A., Kovrigina, N.P. and Rodionova, N.Ju., 2000. Hydrochemical Characteristics of Water of Balaklava Bay and Adjacent Coastal Part of the Black Sea. Hydrobiological Journal, 36(6), 15 p. doi:10.1615/HydrobJ.v36.i6.30

18. Emelianov, V.A., Mitropolskiy, A.Y., Nasedkin, E.I., Pasynkov, A.A., Stepanyak, Yu.D. and Shnyukova, E.E., 2004. [Geoecology of the Black Sea Shelf of Ukraine]. Kiev: Akademperiodika, 141 p. (in Russian).

19. Kotelianets, E.A. and Konovalov, S.K., 2012. Trace Metals in Bottom Sediments of the Kerch Strait. Morskoy Gidrofizicheskiy Zhurnal, (4), pp. 50-60 (in Russian).

20. Romanov, A.S., Orekhova, N.A., Ignatyeva, O.G., Konovalov, S.K. and Ovsyany, E.I., 2007. Influence of Physico-Chemical Characteristics of the Bottom Sediments on the Trace Elements' 
Distribution by the Example of Sevastopol Bays (Black Sea). Ecology of the Sea, (73), pp. 85-90 (in Russian).

About the authors:

Ekaterina A. Kotelyanets - Junior Research Associate, Marine Hydrophysical Institute of RAS (2 Kapitanskaya Str., Sevastopol, 299011, Russian Federation), WoS ResearcherID: AAA-8699-2019, plistus@mail.ru

Konstantin I. Gurov - Junior Research Associate, Marine Hydrophysical Institute of RAS (2 Kapitanskaya Str., Sevastopol, 299011, Russian Federation), ORCID ID: 0000-0003-3460-9650, ResearcherID: L-7895-2017, gurovki@gmail.com

Sergey I. Kondratev - Senior Research Associate, Marine Hydrophysical Institute of RAS (2 Kapitanskaya Str., Sevastopol, 299011, Russian Federation), Ph.D. (Chem.), ResearcherID: F-8972-2019, skondratt@mail.ru

Elena A. Tikhonova - Senior Research Associate, A.O. Kovalevsky Institute of Biology of the Southern Seas of RAS (2 Nakhimov prosp., Sevastopol, 299011, Russian Federation), Ph.D. (Biol.), ORCID ID: 0000-0002-9137-087X, Scopus Author ID: 57208495804,

WoS ResearcherID: X-8524-2019, tihonoval@mail.ru

Contribution of the co-authors:

Ekaterina A. Kotelyanets - formulation of goals and objectives of the study; processing and description of the study results; interpretation of the results; preparation of graphic and text materials; article correction

Konstantin I. Gurov - data preparation; preparation of graphic and text materials; processing and description of the study results

Sergey I. Kondratev - general scientific supervision of scientific developments and scientific research, article correction, advisory assistance

Elena A. Tikhonova - analysis and synthesis of research results selection and analysis of literature, presentation of data in the text and their analysis

All the authors have read and approved the final manuscript.

The authors declare that they have no conflict of interest. 